\title{
Cretaceous Ostracods of North Africa and the Middle East: Paleogeography and Paleoecology
}

\author{
Ashraf M. T. Elewa \\ Geology Department, Faculty of Science, Minia University 61519, Minia, Egypt.
}

*Corresponding Author: Ashraf M. T. Elewa, Geology Department, Faculty of Science, Minia University 61519, Minia, Egypt.

\begin{abstract}
The Cretaceous paleobiogeography of North Africa and the Middle East is detailed through the combination of traditional and novel tools to detect the extinctions of ostracods during the breakup of Gondwana and the drift of the African Plate towards Asia. The multiple causes' scenario of extinctions is established using high resolution quantitative data of 43 selected ostracod species from a total of 136 investigated species belonging to 11 countries of North Africa and the Middle East. The studied ostracod assemblages clarified a possible relationship between the cyclic paleoenvironmental changes, most likely associated with see-saw like oscillations of the African continental plate (specifically during the breakup of Gondwana), and the cyclic variations of the orbit of the Earth. However, further studies of the Asian plate are needed to emphasize the see-saw like oscillations in Asia. On the other hand, three ostracod groups, ranging in age from Aptian to Turonian, have been discriminated, each of which has its paleoecological characteristics.
\end{abstract}

Keywords: Paleogeography; paleoecology; Cretaceous; Ostracods, North Africa; Middle East.

\section{INTRODUCTION}

Since the Belgian geologist D'Halloy established the Cretaceous Period as the last of the Mesozoic Era, and Conybeare and Phillips (1822) divided into Lower and Upper epochs, research on the Cretaceous has received important contributions from several authors on a wide range of different groups of organisms (for example: ammonites, foraminifers, ostracods, vertebrates and others).. As a result, remarkable goals have been achieved regarding Cretaceous paleobiogeography, paleoecology and paleoclimatology.

The ensuing paper introduces the Cretaceous paleobiogeography in response to changes in paleoenvironments and tectonic settings related to the breakup of Gondwana. That is followed by a short note on the Cretaceous ostracods of North Africa and the Middle East, as a step towards detecting any existing relationship between the extinction of Cretaceous ostracods and the dramatical global changes occurred during that time span.

\section{Cretaceous Ostracods of North Africa and the Middle East}

Cretaceous ostracod assemblages of North Africa and the Middle East have been the subject of several previous works; the first known were by Reyment $(1960,1963,1966)$. These were followed by a myriad of authors who focused their research on these regions (Apostolescu, 1961; Grekoff, 1969; Al Sheikhly, 1981; Donze et al., 1982; Bassiouni and Luger, 1990; El Sogher, 1991; Elewa, Bassiouni and Luger, 1999; Elewa, 2002a, b).

Gebhardt (1999) argued for the establishment of a Trans-Saharan Seaway during the Cenomanian and Turonian tectono-eustatic transgressions, grounded in the increased ostracod similarity values in the Turonian and migration of ostracod species across the Sahara. Elewa (2002b) discussing paleobiogeography by means of Maastrichtian to early Eocene ostracod assemblages of North and West Africa and the Middle East concluded there were two main biogeographical provinces that were connected through the Trans-Saharan Seaway. He also confirmed the stability of ostracod habitats in these regions, and no faunal turnover was recorded across the K-Pg boundary (for details on mass extinction as a general, refer to Elewa 2014, and at the K-Pg boundary, refer to Elewa, 2008a, b, c; 
Elewa and Dakrory, 2008a, b; Elewa and Joseph, 2009, as well as the Paleocene-Eocene boundary, see Elewa and Morsi, 2004)).

Luger (2003) pointed out that there is no definite record on Turonian ostracods from the Eastern Arabian Peninsula, including Iraq and Oman, due to a major hiatus in the sedimentary succession. As a result, the studied material of this region in the current study is restricted to the Aptian-Cenomanian intervals.

As a follow up to the work of Elewa (2002b), the present work analyzed the paleobiogeographical and paleoecological implications of ostracod faunas of North Africa and the Middle East by means of multivariate data analyses [for more details on the usage of these techniques to interpret paleoenvironments, refer to Elewa (2004)] to determine the ostracod migration routes, and to recognize the important paleoenvironmental factors affected ostracod migrations and extinctions during the Cretaceous (Aptian to Turonian). Furthermore, this current research tries to find out any existing relation between extinctions and migrations of ostracods and the orbital cycles of the Earth.

\section{MethodS AND TeChNiQueS}

A total of 136 ostracod species of Egypt and the surrounding countries of North Africa and the Middle East have been counted. Forty-three ostracod species ranging from Aptian to Turonian have been selected as appropriate for quantitative faunal analyses; after excluding rare species defined as taxa that have only been observed in three or fewer number of the countries of the studied regions. Moreover, the countries comprising less than three ostracod species were also neglected. The resulting matrix of 43 ostracod species from 11 countries (Table 1; modified after Elewa and Mohamed, 2014) was subjected to Factor analysis with Varimax rotation to infer the paleobiogeographical significances of ostracods in response to global changes. Subsequently, the correlation of the extinctions of ostracod assemblages and the orbital cycles of the Earth relative to the Sun was established.

The multivariate data analyses were done using the PAST statistical package (Hammer et al., 2001), version 2.17b of November, 2012.

Table 1. The studied data matrix (modified after Elewa and Mohamed, 2014).

\begin{tabular}{|c|c|c|c|c|c|c|c|c|c|c|c|c|}
\hline No. & Species & Morocco & Algeria & Tunisia & Libya & Egypt & Israel & \begin{tabular}{|l|} 
Jordan \\
\end{tabular} & Lebanon & Iran & Oman & Kuwait \\
\hline 1 & $\begin{array}{l}\text { Cytherella parallela } \\
\text { (Reuss) }\end{array}$ & 1 & 1 & 0 & 0 & 0 & 1 & 1 & 0 & 0 & 0 & 0 \\
\hline 2 & $\begin{array}{l}\text { Cytherella ovata } \\
\text { (Roemer) }\end{array}$ & 1 & 1 & 0 & 0 & 0 & 1 & 0 & 0 & 0 & 0 & 0 \\
\hline 3 & $\begin{array}{l}\text { Cytherella aegyptiensis } \\
\text { Colin and El Dakkak }\end{array}$ & 1 & 1 & 0 & 0 & 1 & 1 & 0 & 0 & 0 & 0 & 0 \\
\hline 4 & $\begin{array}{l}\text { Paracypris mdaouerensis } \\
\text { Bassoullet and Damotte }\end{array}$ & 1 & 1 & 1 & 1 & 1 & 1 & 1 & 1 & 1 & 1 & 1 \\
\hline 5 & $\begin{array}{l}\text { Monoceratina } \\
\text { trituberculata } \text { Herrig }\end{array}$ & 1 & 1 & 1 & 0 & 0 & 1 & 0 & 0 & 0 & 0 & 0 \\
\hline 6 & $\begin{array}{l}\text { Bythoceratina tamarae } \\
\text { Rosenfeld }\end{array}$ & 0 & 1 & 0 & 1 & 1 & 1 & 0 & 0 & 0 & 0 & 0 \\
\hline 7 & $\begin{array}{l}\text { Brachycythere angulata } \\
\text { Grekoff }\end{array}$ & 0 & 1 & 1 & 1 & 1 & 1 & 0 & 0 & 0 & 0 & 0 \\
\hline 8 & $\begin{array}{l}\text { Mauritsina coronata } \\
\text { Esker }\end{array}$ & 0 & 0 & 1 & 0 & 1 & 1 & 1 & 0 & 0 & 0 & 0 \\
\hline 9 & $\begin{array}{l}\text { Ordoniya ordoniya } \\
\text { (Bassiouni) }\end{array}$ & 0 & 0 & 1 & 1 & 1 & 0 & 1 & 0 & 0 & 0 & 0 \\
\hline 10 & $\begin{array}{l}\text { Paracosta pervinqueri } \\
\text { (Donze and Ra. Said) }\end{array}$ & 1 & 1 & 1 & 0 & 0 & 1 & 0 & 0 & 0 & 0 & 0 \\
\hline 11 & $\begin{array}{l}\text { Amphicytherura distincta } \\
\text { Gerry and Rosenfeld }\end{array}$ & 1 & 1 & 1 & 0 & 0 & 1 & 0 & 0 & 0 & 0 & 0 \\
\hline 12 & $\begin{array}{l}\text { Ovocytheridea reniformis } \\
\text { Bold }\end{array}$ & 1 & 1 & 1 & 0 & 1 & 0 & 1 & 0 & 0 & 0 & 0 \\
\hline 13 & \begin{tabular}{|l} 
Spinoleberis \\
kasserinensis Bismuth \\
and Saint-Marc \\
\end{tabular} & 1 & 1 & 1 & 0 & 0 & 1 & 0 & 0 & 0 & 0 & 0 \\
\hline 14 & $\begin{array}{l}\text { Veeniacythereis } \\
\text { jezzineensis (Bischoff) }\end{array}$ & 0 & 0 & 0 & 0 & 1 & 1 & 0 & 1 & 1 & 1 & 1 \\
\hline 15 & $\begin{array}{l}\text { Oertliella? Tarfayaensis } \\
\text { (Reyment) }\end{array}$ & 1 & 1 & 1 & 0 & 0 & 0 & 0 & 0 & 0 & 0 & 0 \\
\hline 16 & $\begin{array}{l}\text { Reticulocosta } \\
\text { boulhafensis } \text { Viviere }\end{array}$ & 1 & 1 & 1 & 0 & 0 & 0 & 0 & 0 & 0 & 1 & 0 \\
\hline 17 & $\begin{array}{l}\text { Cythereis algeriana } \\
\text { Bischoff }\end{array}$ & 1 & 1 & 1 & 1 & 1 & 1 & 1 & 1 & 1 & 1 & 1 \\
\hline 18 & Cythereis magnei Donze & 1 & 1 & 1 & 0 & 0 & 0 & 0 & 0 & 0 & 0 & 0 \\
\hline
\end{tabular}


Cretaceous ostracods of North Africa and the Middle East: Paleogeography and Paleoecology

\begin{tabular}{|c|c|c|c|c|c|c|c|c|c|c|c|c|}
\hline & and Saint-Marc & & & & & & & & & & & \\
\hline 19 & $\begin{array}{l}\text { Xestoleberis tunisiensis } \\
\text { Esker }\end{array}$ & 0 & 1 & 1 & 0 & 1 & 0 & 0 & 0 & 0 & 0 & 0 \\
\hline 20 & $\begin{array}{l}\text { Pontocyprella recurva } \\
\text { Esker }\end{array}$ & 0 & 1 & 1 & 1 & 1 & 0 & 0 & 0 & 0 & 0 & 0 \\
\hline 21 & $\begin{array}{l}\text { Actinocythereis coronata } \\
\text { (Esker) }\end{array}$ & 0 & 1 & 1 & 1 & 1 & 0 & 0 & 0 & 0 & 0 & 0 \\
\hline 22 & Krithe echolsae Esker & 0 & 0 & 1 & 0 & 1 & 1 & 0 & 0 & 0 & 0 & 0 \\
\hline 23 & $\begin{array}{l}\text { Cytherella gambiensis } \\
\text { Apostolescu }\end{array}$ & 0 & 1 & 1 & 0 & 1 & 0 & 0 & 0 & 0 & 0 & 0 \\
\hline 24 & $\begin{array}{l}\text { Dolocytheridea atlassica } \\
\text { Bassoullet and Damotte }\end{array}$ & 0 & 1 & 1 & 0 & 1 & 1 & 0 & 0 & 0 & 0 & 0 \\
\hline 25 & $\begin{array}{l}\text { Peloriops ziregensis } \\
\text { (Bassoullet and Damotte) }\end{array}$ & 1 & 1 & 1 & 1 & 1 & 1 & 1 & 1 & 1 & 1 & 1 \\
\hline 26 & $\begin{array}{l}\text { Cythereis namousensis } \\
\text { Bassoullet and Damotte }\end{array}$ & 0 & 1 & 1 & 0 & 1 & 1 & 0 & 0 & 0 & 0 & 0 \\
\hline 27 & $\begin{array}{l}\text { Veeniacythereis } \\
\text { maghrebensis (Bassoullet } \\
\text { and Damotte) }\end{array}$ & 0 & 1 & 1 & 0 & 1 & 1 & 0 & 0 & 0 & 1 & 1 \\
\hline 28 & \begin{tabular}{|l|} 
Metacytheropteron \\
berbericum (Bassoullet \\
and Damotte)
\end{tabular} & 1 & 1 & 1 & 0 & 1 & 1 & 0 & 0 & 1 & 1 & 0 \\
\hline \begin{tabular}{|l|}
29 \\
\end{tabular} & $\begin{array}{l}\text { Peloriops pustulata } \\
\text { (Rosenfeld and Raab) }\end{array}$ & 0 & 0 & 1 & 0 & 1 & 1 & 0 & 0 & 0 & 1 & 1 \\
\hline 30 & $\begin{array}{l}\text { Centrocythere tunetana } \\
\text { Bismuth and Donze }\end{array}$ & 0 & 1 & 1 & 0 & 1 & 1 & 0 & 0 & 0 & 0 & 0 \\
\hline 31 & $\begin{array}{l}\text { Bairdia youssefi } \\
\text { Bassiouni }\end{array}$ & 0 & 1 & 1 & 0 & 1 & 0 & 0 & 0 & 0 & 0 & 0 \\
\hline 32 & $\begin{array}{l}\text { Amphicytherura } \\
\text { (Sondagella) falloti } \\
\text { Donze and Thomel }\end{array}$ & 0 & 1 & 1 & 0 & 1 & 0 & 0 & 0 & 0 & 0 & 0 \\
\hline 33 & $\begin{array}{l}\text { Eucytherura gruendeli } \\
\text { Weaver }\end{array}$ & 0 & 1 & 1 & 0 & 1 & 0 & 0 & 0 & 0 & 0 & 0 \\
\hline 34 & $\begin{array}{l}\text { Paracypris dubertreti } \\
\text { Damotte and Saint-Marc }\end{array}$ & 1 & 1 & 0 & 0 & 1 & 1 & 0 & 1 & 0 & 0 & 0 \\
\hline 35 & $\begin{array}{l}\text { Sinaiella halaliensis } \\
\text { Bassiouni }\end{array}$ & 0 & 0 & 1 & 0 & 1 & 1 & 0 & 0 & 0 & 0 & 0 \\
\hline \begin{tabular}{|l|}
36 \\
\end{tabular} & $\begin{array}{l}\text { Rehacythereis zoumoffeni } \\
\text { (Bischoff) }\end{array}$ & 0 & 0 & 0 & 0 & 1 & 1 & 0 & 1 & 0 & 0 & 0 \\
\hline 37 & $\begin{array}{l}\text { Schuleridea baidarensis } \\
\text { (Damotte and Saint- } \\
\text { Marc) }\end{array}$ & 0 & 0 & 0 & 0 & 1 & 1 & 0 & 1 & 1 & 1 & 0 \\
\hline 38 & $\begin{array}{l}\text { Centrocythere } \\
\text { sanninensis Morphotype } \\
\text { A Damotte and Saint- } \\
\text { Marc }\end{array}$ & 0 & 0 & 1 & 0 & 1 & 1 & 0 & 1 & 0 & 0 & 0 \\
\hline 39 & $\begin{array}{l}\text { Centrocythere } \\
\text { sanninensis Morphotype } \\
\text { B Damotte and Saint- } \\
\text { Marc }\end{array}$ & 0 & 0 & 1 & 0 & 1 & 1 & 0 & 1 & 0 & 0 & 0 \\
\hline 40 & $\begin{array}{l}\text { Hiltermannia majestica } \\
\text { Bassiouni }\end{array}$ & 0 & 0 & 0 & 0 & 1 & 1 & 0 & 0 & 1 & 0 & 0 \\
\hline 41 & $\begin{array}{l}\text { Rehacythereis btaterensis } \\
\text { interstincta (Bischoff) }\end{array}$ & 0 & 0 & 0 & 0 & 1 & 1 & 0 & 1 & 0 & 0 & 0 \\
\hline 42 & $\begin{array}{l}\text { Rehacythereis btaterensis } \\
\text { btaterensis (Bischoff) }\end{array}$ & 0 & 0 & 1 & 0 & 1 & 1 & 0 & 1 & 0 & 0 & 0 \\
\hline \begin{tabular}{|l|}
43 \\
\end{tabular} & \begin{tabular}{|l} 
Veeniacythereis \\
streblolophata (Al- \\
Abdul-Razzaq)
\end{tabular} & 0 & 0 & 1 & 0 & 1 & 0 & 0 & 0 & 1 & 0 & 1 \\
\hline
\end{tabular}

\section{FACTOR ANALYSIS}

In the present study, Factor analysis technique with Varimax rotation has been applied to the data matrix (the summary of this analysis is shown in table 2).

Table 2. Summary of Factor analysis.

\begin{tabular}{|c|c|c|c|}
\hline Component & Eigenvalue & \% variance & Cumulative \% \\
\hline 1 & 25.42 & 59.12 & 59.12 \\
\hline 2 & 5.5883 & 13.00 & 72.12 \\
\hline 3 & 3.8432 & 8.94 & $\underline{81.06}$ \\
\hline
\end{tabular}

From table 2 it is clear that the first three components are suitable for representation of the total variance of the studied data; as they account for more than $81 \%$ of total variance. 
By means of this technique three ostracod groups could be distinguished (fig. 1; table 3): Group A (fig. 1; table 3) mostly represents the Cenomanian-Turonian ostracod assemblages of Morocco, Algeria, Tunisia, and Israel (mainly western countries of North Africa). This group indicates relatively high positive scores of the $1^{\text {st }}$ component for Morocco, Algeria, Israel, and Tunisia, and relatively high negative score of the $1^{\text {st }}$ component for Egypt (Fig. 2). It includes nine ostracod species, in which the following are significant: Cytherella parallela (no. 1 in fig. 1); Cytherella ovata (no. 2 in fig. 1); Monoceratina trituberculata (no. 5 in fig. 1); Aracajuia distincta (no. 11 in fig. 1); Oertliella? tarfayaensis (no. 15 in fig. 1). The aforementioned species of this group probably indicate reduced oxygen conditions in the rarity of Buntonia species (see Peypouquet et al., 1986, and Whatley, 1991 for Cytherella; Carbonnel and Johnson, 1989 for Buntonia). Therefore, high positive scores of the $1^{\text {st }}$ component represent reduced oxygen conditions of water, while the relatively negative scores represent normal oxygenation.

Group B (fig. 1; table 3) consists of species that consistently took place in the successions of the Cenomanian of North Africa and the Middle East as well. This group shows relatively high positive scores of the $2^{\text {nd }}$ component for Morocco and Algeria, and relatively high negative scores of the $2^{\text {nd }}$ component for Israel, Egypt, and Lebanon (Fig. 1). Among the common species of this group: Cytherella aegyptiensis (no. 3 in fig. 1); Paracypris mdaouerensis (no.4; fig. 1); Cythereis algeriana (no. 17 in fig. 1); Xestoleberis tunisiensis (no. 19 in fig. 1); Pontocyprella recurva (no. 20 in fig. 1); Peloriops ziregensis (no. 25 in fig. 1), Veeniacythereis maghrebensis (no. 27 in fig. 1); Metacytheropteron berbericum (no. 28 in fig. 1); Paracypris dubertreti (no. 34 in fig. 1). It shows relatively high positive scores of the $2^{\text {nd }}$ component for Morocco and Algeria, and relatively high negative scores of the $2^{\text {nd }}$ component for Israel, Egypt, and Lebanon. Elewa (2002a) recorded Peloriops ziregensis as a representative of the open marine, shallow water associations of a shallow ramp facies belt, without major influence of wave activity. Morsi (2006) assigned species belonging to the genera: Cytherella, Paracypris, Metacytheropteron, and Veeniacythereis, and some other genera, to_normal open marine environments, characteristic of shallow, littoral depths. This indicates the domination of shallow marine ostracod assemblages in the eastern part of North Africa and the Middle East during Cenomanian times. On the other hand, the western countries of North Africa (Morocco and Algeria) revealed relatively deeper water conditions than the eastern part of North Africa and the Middle East.

Group C (fig. 1; table 3) is represented by a collection of species that are common to North Africa and the Middle East during the Aptian to Cenomanian times. The group exhibits relatively high positive scores of the $3^{\text {rd }}$ component for Israel, Morocco, and Lebanon, and clarifies relatively high negative scores of the $3^{\text {rd }}$ component for Tunisia, Egypt, Algeria, and Libya (Fig. 2). It mainly comprises the following ostracod species: Mauritsina coronata (no. 8 in fig. 1); Ordoniya ordoniya (no. 9 in fig. 1); Veeniacythereis jezzineensis (no. 14 in fig. 1); Krithe echolsae (no. 22 in fig. 1); Peloriops pustulata (no. 29 in fig.1);. 1); Schuleridea baidarensis (no. 37 in fig. 1); Centrocythere sanninensis MTA (no. 38 in fig. 1); C. sanninensis MTB (no. 39 in fig. 1); Hiltermannia majestica (no. 40 in fig. 1); Rehacythereis btaterensis interstincta (no. 41 in fig. 1); Rehacythereis btaterensis btaterensis (no. 42 in fig. 1); Veeniacythereis streblolophata schista (no. 43 in fig. 1).

Elewa and Morsi (2004), and Elewa (2007) defined most species mentioned for this group to inhabit an outer shelf to upper bathyal depths. Rosenfeld and Raab (1984) stated that the environment of deposition of Centrocythere sanninensis MTA is shallow (littoral), warm, marine environment with water depths not exceeding $200 \mathrm{~m}$, while for Centrocythere sanninensis MTB is deeper and could possibly even extend to $1000 \mathrm{~m}$. The simultaneous occurrence of these two morphs in group $\mathrm{C}$ indicates the effect of water turbulence in having the shallower morph (MTA) together with the deeper one (MTB) in the same environment. Elewa (2002a) stated that MTB could tolerate wider range of salinity than MTA, indicating the fluctuation of salinity levels in this group. As a result, the occurrence of ostracod species of an outer shelf to upper bathyal depths (according to Elewa and Morsi, 2004; Elewa, 2007), with fluctuation in salinity degrees (according to Elewa, 2002a) in Egypt are represented by the relatively high negative scores of the $3^{\text {rd }}$ component; while the relatively high positive scores of the $3^{\text {rd }}$ component would indicate the effect of water turbulence (according to Rosenfeld and Raab, 1984). 


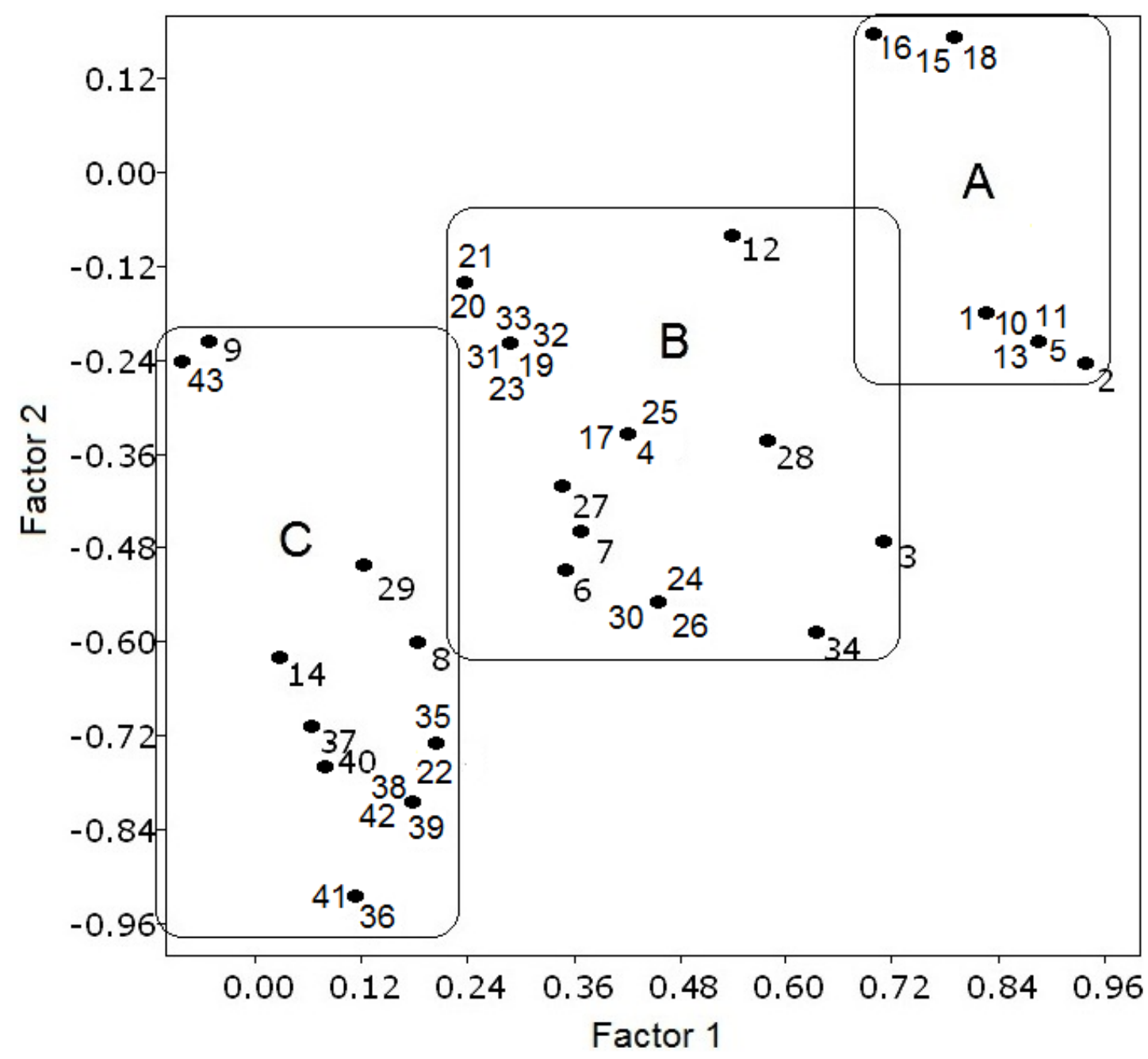

Fig. 1. Varimax factors scatter plot for 43 ostracod species from 11 countries of the studied regions.
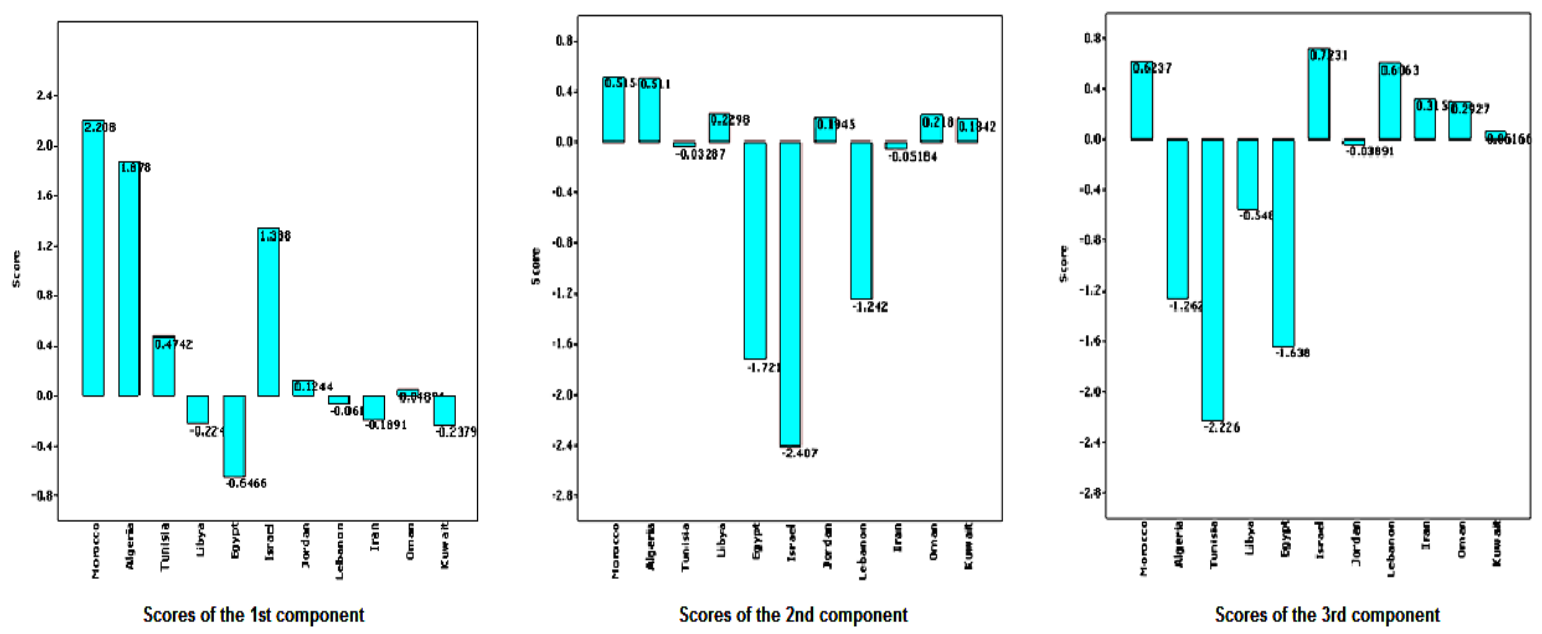

Fig. 2. Factor scores of the $1^{\text {st }}, 2^{\text {nd }}$, and $3^{\text {rd }}$ components for 11 countries of the studied regions.

The graph indicates relatively high positive scores of the $1^{\text {st }}$ component for Morocco, Algeria, Israel, and Tunisia. It shows relatively high negative score of the $1^{\text {st }}$ component for Egypt. The graph shows relatively high positive scores of the $2^{\text {nd }}$ component for Morocco and Algeria. It shows relatively high negative scores of the $2^{\text {nd }}$ component for Israel, Egypt, and Lebanon. The graph exhibits relatively high positive scores of the $3^{\text {rd }}$ component for Israel, Morocco, and Lebanon. It clarifies relatively high negative scores of the $3^{\text {rd }}$ component for Tunisia, Egypt, Algeria, and Libya. 
Cretaceous ostracods of North Africa and the Middle East: paleogeography and paleoecology

Table 3. The frequent occurrence of the studied ostracods in the Aptian to Turonian of North Africa and the Middle East.

\begin{tabular}{|c|c|c|c|c|c|c|}
\hline Group & No. & Ostracod species & Aptian & Albian & Cenomanian & Turonian \\
\hline $\mathbf{C}$ & 41 & $\begin{array}{l}\text { Rehacythereisis btaterensis } \\
\text { interstincta }\end{array}$ & 1 & $\mathbf{0}$ & $\mathbf{0}$ & $\mathbf{0}$ \\
\hline $\mathbf{C}$ & 42 & $\begin{array}{l}\text { Rehacythereisis btaterensis } \\
\text { btaterensis }\end{array}$ & 1 & $\mathbf{0}$ & $\mathbf{0}$ & $\mathbf{0}$ \\
\hline $\mathbf{C}$ & 35 & Sinaiella halaliensis & 1 & 1 & $\mathbf{0}$ & $\mathbf{0}$ \\
\hline $\mathbf{C}$ & 38 & Centrocythere sanninensis MTA & 1 & 1 & $\mathbf{0}$ & $\mathbf{0}$ \\
\hline $\mathbf{C}$ & 39 & Centrocythere sanninensis MTB & 1 & 1 & $\mathbf{0}$ & $\mathbf{0}$ \\
\hline $\mathbf{C}$ & 40 & Hiltermannia majestica & 1 & 1 & $\mathbf{0}$ & $\mathbf{0}$ \\
\hline $\mathbf{C}$ & 37 & Schuleridea baidarensis & 1 & 1 & 1 & $\mathbf{0}$ \\
\hline $\mathbf{A}$ & 1 & Cytherella parallela & 1 & 1 & 1 & 1 \\
\hline $\mathbf{A}$ & 2 & Cytherella ovata & 1 & 1 & 1 & 1 \\
\hline $\mathbf{B}$ & 4 & Paracypris mdaouerensis & 1 & 1 & 1 & 1 \\
\hline B & 34 & Paracypris dubertreti & 1 & 1 & 1 & 1 \\
\hline $\mathbf{C}$ & 36 & Rehacythereisis zoumoffeni & $\mathbf{0}$ & 1 & $\mathbf{0}$ & $\mathbf{0}$ \\
\hline $\mathbf{C}$ & 8 & Mauritsina coronata & $\mathbf{0}$ & 1 & 1 & $\mathbf{0}$ \\
\hline $\mathbf{A}$ & 15 & Oertliella? tarfayaensis & $\mathbf{0}$ & 1 & 1 & $\mathbf{0}$ \\
\hline B & 19 & Xestoleberis tunisiensis & $\mathbf{0}$ & 1 & 1 & $\mathbf{0}$ \\
\hline B & 20 & Pontocyprella recurva & $\mathbf{0}$ & 1 & 1 & $\mathbf{0}$ \\
\hline $\mathbf{C}$ & 22 & Krithe echolsae & $\mathbf{0}$ & 1 & 1 & $\mathbf{0}$ \\
\hline B & 30 & Centrocythere tunetana & $\mathbf{0}$ & 1 & 1 & $\mathbf{0}$ \\
\hline B & 31 & Bairdia youssefi & $\mathbf{0}$ & 1 & 1 & $\mathbf{0}$ \\
\hline B & 32 & Amphicytherura (Sondagella) falloti & $\mathbf{0}$ & 1 & 1 & $\mathbf{0}$ \\
\hline B & 33 & Eucytherura gruendeli & $\mathbf{0}$ & 1 & 1 & $\mathbf{0}$ \\
\hline B & 17 & Cythereis algeriana & $\mathbf{0}$ & 1 & 1 & 1 \\
\hline B & 24 & Dolocytheridea atlassica & $\mathbf{0}$ & 1 & 1 & 1 \\
\hline B & 28 & Metacytheropteron berbericum & $\mathbf{0}$ & 1 & 1 & 1 \\
\hline B & 3 & Cytherella aegyptiensis & $\mathbf{0}$ & $\mathbf{0}$ & 1 & $\mathbf{0}$ \\
\hline $\mathbf{C}$ & 14 & Veeniacythereis jezzineensis & $\mathbf{0}$ & $\mathbf{0}$ & 1 & $\mathbf{0}$ \\
\hline B & 25 & Peloriops ziregensis & $\mathbf{0}$ & $\mathbf{0}$ & 1 & $\mathbf{0}$ \\
\hline B & 26 & Cythereis namousensis & $\mathbf{0}$ & $\mathbf{0}$ & 1 & $\mathbf{0}$ \\
\hline B & 27 & Veeniacythereis maghrebensis & $\mathbf{0}$ & $\mathbf{0}$ & 1 & $\mathbf{0}$ \\
\hline $\mathbf{C}$ & 29 & Peloriops pustulata & $\mathbf{0}$ & $\mathbf{0}$ & 1 & $\mathbf{0}$ \\
\hline $\mathbf{C}$ & 43 & Veeniacythereis streblolophata & $\mathbf{0}$ & $\mathbf{0}$ & 1 & $\mathbf{0}$ \\
\hline B & 6 & Bythoceratina tamarae & $\mathbf{0}$ & $\mathbf{0}$ & 1 & $\mathbf{0}$ \\
\hline $\mathbf{A}$ & 16 & Reticulocosta boulhafensis & $\mathbf{0}$ & $\mathbf{0}$ & 1 & $\mathbf{0}$ \\
\hline $\mathbf{A}$ & 5 & Monoceratina trituberculata & $\mathbf{0}$ & $\mathbf{0}$ & 1 & 1 \\
\hline $\mathbf{A}$ & 11 & Amphicytherura distincta & $\mathbf{0}$ & $\mathbf{0}$ & 1 & 1 \\
\hline B & 23 & Cytherella gambiensis & $\mathbf{0}$ & $\mathbf{0}$ & 1 & 1 \\
\hline B & 7 & Brachycythere angulata & $\mathbf{0}$ & $\mathbf{0}$ & $\mathbf{0}$ & 1 \\
\hline $\mathbf{C}$ & 9 & Ordoniya ordoniya & $\mathbf{0}$ & $\mathbf{0}$ & $\mathbf{0}$ & 1 \\
\hline $\mathbf{A}$ & 10 & Paracosta pervinqueri & $\mathbf{0}$ & $\mathbf{0}$ & $\mathbf{0}$ & 1 \\
\hline $\mathbf{A}$ & 18 & Cythereis magnei & $\mathbf{0}$ & $\mathbf{0}$ & $\mathbf{0}$ & 1 \\
\hline B & 21 & Actinocythereis coronata & $\mathbf{0}$ & $\mathbf{0}$ & $\mathbf{0}$ & 1 \\
\hline B & 12 & Ovocytheridea reniformis & $\mathbf{0}$ & $\mathbf{0}$ & $\mathbf{0}$ & 1 \\
\hline A & 13 & Spinoleberis kasserinensis & $\mathbf{0}$ & $\mathbf{0}$ & $\mathbf{0}$ & 1 \\
\hline
\end{tabular}

\section{Paleo Environmental Reconstruction Based on OStracod Provinciality}

Factor Analysis enabled to clarify the paleoenvironmental conditions under which the studied Cretaceous ostracod assemblages were distributed in the countries of North Africa and the Middle East. The obtained three ostracod groups are ranging in age from Aptian to Turonian, with group C representing the Aptian to Cenomanian intervals, and clarifies species inhabited turbulent water conditions in Israel, Morocco, and Lebanon; meanwhile Tunisia, Egypt, Algeria, and Libya were affected by fluctuation in both depth and salinity levels. In the Cenomanian, the countries of the eastern part of North Africa and the Middle East (group B) have shown the domination of shallow marine ostracod assemblages. Nonetheless, the western countries of North Africa (Morocco and Algeria) revealed relatively deeper water conditions than the eastern part of North Africa and the Middle East during the Cenomanian time. Finally, in the Cenomanian-Turonian intervals, ostracod assemblages (group A) of Morocco, Algeria, and Tunisia, and Israel (western countries of North Africa, and Israel from Asia) have lived in reduced oxygen conditions; but Egypt in contrast, has shown normal oxygen levels of water.

\section{EXTINCTION EXPOSURE TO ORBITAL CYCLES AND BREAKUP OF GONDWANA}

Milankovitch $(1920,1941)$ introduced his mathematical theory linking orbital elements to insolation, and insolation to climate changes. However, Roth (1989) Supposed that the superimposed, astronomically driven Milankovitch cycles affected relative abundance patterns but not taxonomic 
evolution of calcareous nannoplankton. Berger (1978) designed in an analytical form the Fourier decomposition of the Earth's orbital parameters applicable for the astronomical theory of palaeoclimates. Recently, Laskar et al. (2004) expected the solution for obliquity to be valid over the last $20 \mathrm{Myr}$ with a 5\% error in tidal dissipation; however, the error may increase to $10 \%$ beyond 20Ma. More recent, Laskar et al. (2010) represented a new solution for the astronomical computation of the orbital motion of the Earth spanning from 0 to $-250 \mathrm{Myr}$.

Marusek (2005) proposed two primary mechanisms responsible for the global mass extinctions over the past 500 million years: Oort cloud comet impacts and nearby supernova events. As to the Cretaceous, Tyszka (2009) clued that his study of the Albian record from the Lower Saxony Basin confronted with the presented conceptual model and former climate models supports the conclusion that the temperate zone surrounding Tethys was sensitive to seasonal changes modulated by orbital cyclicity. Meanwhile, Mitchell et al. (2008) noticed that the lead up to the second global oceanicanoxic event of the Cretaceous (OAE 2) of the Scaglia Bianca Formation, in the Umbria and Marche regions of Italy, is characterized by a robust set of cycles whose periods are remarkably similar to the orbital cycles calculated by Laskar et al. (2004). Herbert (1992) stated that bedded pelagic limestones of early to mid Cretaceous age may record cyclic climate variability driven by changes in the Earth's orbit (Milankovitch cycles).

Results of the study of Aptian to Turonian ostracods herein performed indicate cyclic changes in the paleoenvironmental conditions, probably associated with see-saw like oscillations of the African continental plate during the breakup of Gondwana, that may correlate with the cyclic changes occurred in the orbit of our planet Earth due to the variation of distances of the orbit towards the Sun through time. These cyclic changes subsequently led to either migration or extinction of ostracod assemblages of the studied regions of North Africa and the Middle East.

\section{EXTINCTION VS. MIGRATION}

Some authors believe in a minor extinction event during the Aptian times, which mainly affected marine life on the genus rather than on family levels (Raup and Sepkoski, 1984; Sepkoski, 1996). McAnena et al. (2013) could assess the timing and magnitude of late Aptian cooling and its association with biotic crises using a suite of geochemical and micropalaeontological assessments from a marine sediment core from the North Atlantic Ocean combined with global biogeochemical modelling. Reyment $(1969,1971)$ stated that Albian to Turonian transgressions around the coast of Africa displayed a type of correlative pattern that suggests they may be the results of a see-saw motion. The study of dinoflagellate cysts (Masure and Vrielynck, 2009) evidenced that during the Late Albian a warm deep ocean coexisted with relatively cool, high latitude surface water in the northern hemisphere and warmer high latitude surface water surface in the southern hemisphere. Seemingly, Shen (2008) believed that the Cenomanian-Turonian times were exposed to enhanced flux of volcanic ash that inputted micro-nutrient iron into the ocean, fertilizing surface waters and generating a global phytoplanktonic bloom, which in turn depleted oxygen levels in deep ocean environments.

Apart of that, one of the most interesting phenomena is the Lilliput Effect, first mentioned by Urbanek (1993) in his study of biotic crises in the history of Upper Silurian graptoloids. It states that the extant taxa above the extinction boundary have a tendency to be dwarfed in comparison to those recognized in pre-extinction assemblages (Twitchett, 2006; Elewa and Dakrory, 2008a; Wade and Twitchett, 2009; Harries and Knorr, 2009). Elewa and Dakrory (2008a) noticed the Lilliputian planktonic foraminiferal assemblages of the K-Pg boundary of the North African Plate.

As to the history of migration of the studied ostracod assemblages, it started in Aptian-Albian times (fig. 3; table 4$)$ with prevailed warm water conditions $\left(1^{\text {st }}\right.$ cycle of paleoenvironmental changes during the "perihelion stage" when Earth was the closest to the Sun). These were disrupted by interludes of global cooling, associated to fluctuation in both sea level and salinity. These unstable environmental conditions forced deep marine ostracod species of the East South Tethyan Province (ESTP) to migrate westward towards Egypt in the Albian- early Cenomanian (fig. 3; table 4), where the depth of water was outer shelf to upper bathyal with cooler conditions $\left(2^{\text {nd }}\right.$ cycle of paleoenvironmental changes during the "ahelion stage" when Earth was farthest from the Sun). This east-west migration was probably supported by the movement of the African Plate towards Asia span the breakup of Gondwana. Though, ostracod species that could not migrate have been suffered and vanished due to 
the Aptian-Albian crisis. In the Cenomanian (fig. 3; table 4), shallow water conditions prevailed in the south of the Asian Province, and opened the way to shallow ostracod species to migrate from the north and dominate in the south $\left(3 \mathrm{r}^{\mathrm{d}}\right.$ cycle of paleoenvironmental changes during the "perihelion stage" when Earth was closest to the Sun). For the duration of the Cenomanian-Turonian times (fig. 3; table 4), the deteriorated environmental conditions, which are represented by the reduction of oxygen content of water (Bonarelli Event; $4^{\text {th }}$ cycle of paleoenvironmental changes during the "ahelion stage" when the Earth is farthest to the Sun; low ${ }^{18} \mathrm{O} /{ }^{16} \mathrm{O}$ ratio), caused the survival of those ostracod species that are able to tolerate oxygen depletion within the western countries of North Africa (Morocco, Algeria, and Tunisia), while the other species had became extinct. However, it is noticeable that predation played an important role in the diversity of ostracods belonging to the Western Type Fauna, where ostracod species like Cytherella (which is common in this region) display the "Obligatory Predation" phenomenon of Elewa (2007). This author applied the terminology of Corbari et al. (2005) in which ostracod species that could adapt with reduced oxygen conditions (for example: Cytherella) stayed in deep water away from predators of the surface water; hence they are represented by high abundance in this region.

Table 4. Summary of events related to orbital cycles of Earth in the studied regions of North Africa and the Middle East.

\begin{tabular}{|c|c|c|c|c|c|c|}
\hline Region & Countries & Age & Orbital cycle & $\begin{array}{c}\text { See-saw motion of } \\
\text { the African } \\
\text { continental plate (in } \\
\text { accordance with } \\
\text { Reyment 1971) }\end{array}$ & $\begin{array}{c}\text { Paleoenvironmental } \\
\text { changes }\end{array}$ & Event \\
\hline \begin{tabular}{c|} 
East South \\
Tethyan \\
Province (Asia) \\
(ESTPAS)
\end{tabular} & $\begin{array}{l}\text { Lebanon, } \\
\text { Iran, Israel }\end{array}$ & Aptian-Albian & $\begin{array}{l}1^{\text {st }} \text { (perihelion } \\
\text { stage) }\end{array}$ & No data available & $\begin{array}{c}\text { Warm water conditions } \\
\text { with interludes of global } \\
\text { cooling, associated with } \\
\text { fluctuation in both sea level } \\
\text { and salinity }\end{array}$ & East-West migration \\
\hline $\begin{array}{l}\text { East South } \\
\text { Tethyan } \\
\text { Province } \\
\text { (Africa) } \\
\text { (ESTPAF) }\end{array}$ & Egypt & $\begin{array}{c}\text { Albian- } \\
\text { Cenomanian }\end{array}$ & $\begin{array}{c}2^{\text {nd }} \text { (ahelion } \\
\text { stage) }\end{array}$ & $\begin{array}{c}\text { Albian-Cenomanian } \\
\text { Transgression (ACT; } \\
\text { Figure 7) }\end{array}$ & $\begin{array}{l}\text { Outer shelf to upper } \\
\text { bathyal marine } \\
\text { environments with cooler } \\
\text { conditions }\end{array}$ & East-West migration \\
\hline $\begin{array}{l}\text { Asian Province } \\
\text { (ASP) }\end{array}$ & $\begin{array}{l}\text { Saudi Arabia, } \\
\text { Kuwait, } \\
\text { Oman } \\
\end{array}$ & Cenomanian & $\begin{array}{l}3^{\text {rd }} \text { (perihelion } \\
\text { stage) }\end{array}$ & No data available & Shallow water conditions & $\begin{array}{l}\text { North-South } \\
\text { migration }\end{array}$ \\
\hline $\begin{array}{l}\text { West South } \\
\text { Tethyan } \\
\text { Province } \\
\text { (Africa) } \\
\text { (WESTPAF) }\end{array}$ & $\begin{array}{l}\text { Algeria, } \\
\text { Tunisia, } \\
\text { Morocco }\end{array}$ & $\begin{array}{c}\text { Cenomanian- } \\
\text { Turonian }\end{array}$ & $\begin{array}{c}4^{\text {th }} \text { (ahelion } \\
\text { stage) }\end{array}$ & \begin{tabular}{|c|} 
Cenomanian-Turonian \\
Transgression (CTT; \\
Figure 9)
\end{tabular} & $\begin{array}{l}\text { Reduced oxygen content of } \\
\text { water (Bonarelli Event) } \\
\text { exposure to predation of } \\
\text { ostracods }\end{array}$ & $\begin{array}{c}\text { Survival/Extinction } \\
\text { Event }\end{array}$ \\
\hline
\end{tabular}
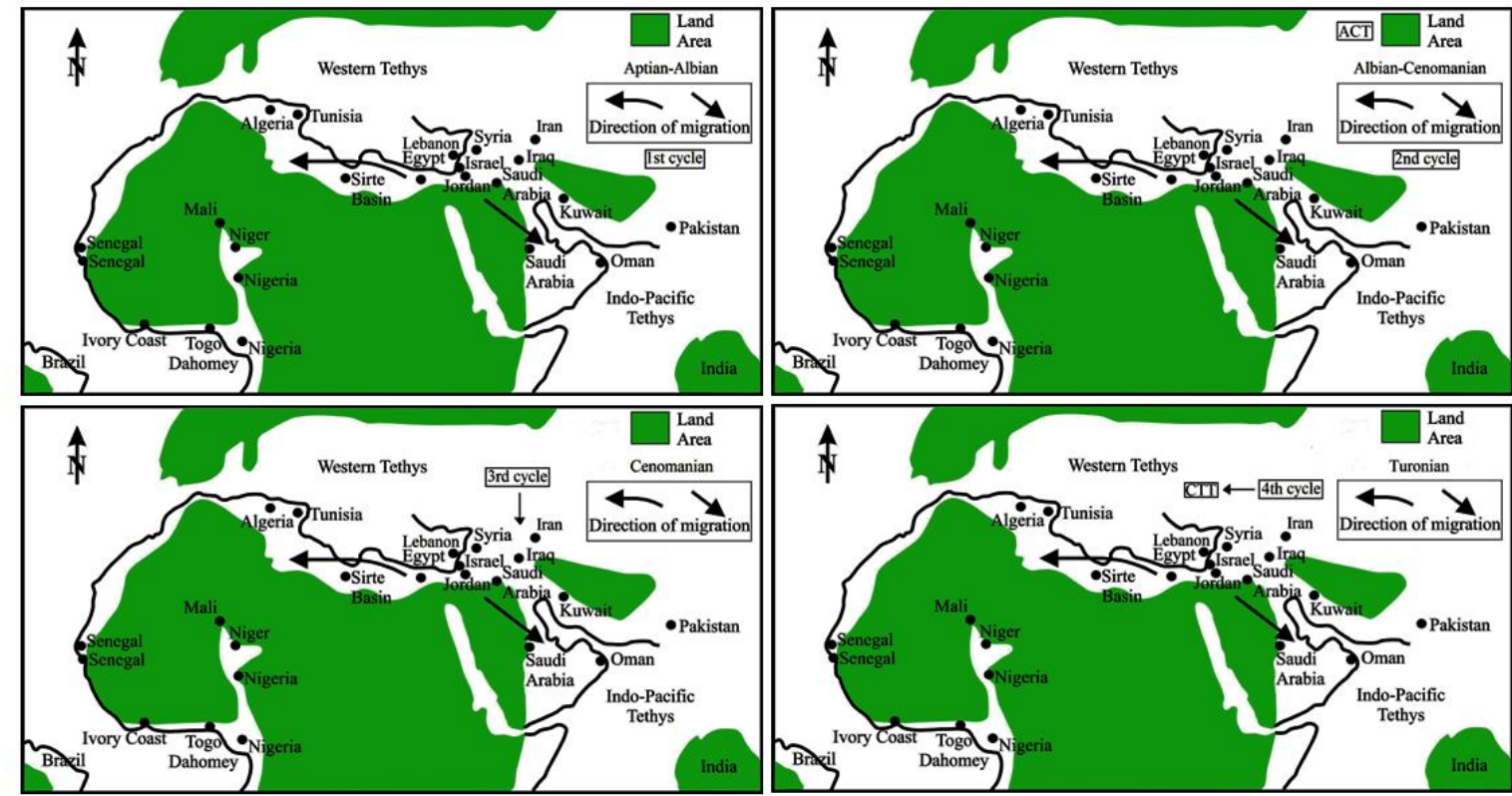

Fig. 3. 
Representation of the four recognized cycles of paleoenvironmental changes within the studied regions (basic map modified after Elewa and Mohamed, 2014); black lines refer to the present day borders of lands. The $1^{\text {st }}$ cycle of paleoenvironmental changes started in the East South Tethyan Province. The $2^{\text {nd }}$ cycle of paleoenvironmental changes led to migration of ostracods from east to west. ACT: Albian-Cenomanian Transgression. The $3^{\text {rd }}$ cycle of paleoenvironmental changes led to migration of ostracods from north to south. The $4^{\text {th }}$ cycle of paleoenvironmental changes occurred within the Western Type Fauna of North Africa. CTT: Cenomanian-Turonian Transgression.

\section{CONCLuSiOnS}

Ostracods in the studied regions range in age from Aptian to Turonian, and are reported from Jordan, Israel, Lebanon, Kuwait, Oman and Iran in the east through Egypt and the other North African countries in the west.

The most common genera in the studied regions belong to Cytherella, Cythereis, Veeniacythereis, and Rehacythereisis. The most frequent species were Cythereis algeriana, Peloriops ziregensis, Metacytheropteron berbericum, Veeniacythereis maghrebensis, Paracypris mdaouerensis, Ovocytheridea reniformis, Veeniacythereis jezzineensis, Peloriops pustulata and Paracypris dubertreti.

Present results point to the existence of a shallow marine transcontinental connection between the ESTP and the Western South Tethyan Province (WSTP) of the studied regions during the AptianTuronian. Meanwhile, a connection between the north and the south is established within the ostacod species of the Arabian Peninsula in the Aptian - Cenomanian. These results correlate to those of Luger (2003), who recognized an increasingly uniform pan - South Tethyan ostracod province (North Africa and the Arabian Peninsula) through the Aptian to Cenomanian times.

Moreover, the present study revealed a possible correlation between cyclic paleoenvironmental changes led to extinction and migration of ostracods and the orbital changes of Earth during the intervals of plate tectonic activities; during the breakup of Gondwana, and the shift of the African Plate towards Asia.

\section{ACKNOWLEDGEMENT}

The author is much indebted to Pro. Dr. Richard A. Reyment, the fellow of the Royal Swedish Academy of Sciences, for his review of the early version of present work.

\section{REFERENCES}

Al Sheikhly, S.A.J., 1981. Maastrichtian - upper Eocene Ostracoda of the subfamily Trachyleberidinae from Iraq, Jordan and Syria. Unpublished Ph.D. Thesis, University of Glasgow, $229 \mathrm{p}$.

Apostolescu, V., 1961. Contribution à l'étude paléontologique (Ostracodes) et stratigraphique des bassins cretacés et tertiaires de l'Afrique Occidentale. Rév. Inst. Franc. Pétrole, Paris, v. 16, nos. 7-8, p. 779-867.

Bassiouni, A., and Luger, P., 1990. Maastrichtian to early Eocene Ostracoda from Southern Egypt (paleontology, paleoecology, paleobiogeography and biostratigraphy). Berliner Geowiss Abh (A), v. 120, no. 2, p. 755-928.

Berger, A., 1978. Long-term variation of daily insolation and Quaternary climatic changes, J. Atmos. Sci., v. 35, p. 2362-2367.

Carbonnel, G., and Johnson, A., 1989. Les ostracodes Paleogenes du Togo: taxonomie, biostratigraphie, apports dans l'organisation et l'evolution du basin. Gébios, 22: 409-443.

Conybeare, W. D., and Phillips, W., 1822. Outlines of the geology of England rud Wales. Part I. London: Wm. Phillips, $471 \mathrm{p}$.

Corbari, L., Mesmer-Dudons, N., Carbonel, P., and Massabuau, J.C., 2005. Cytherella

as a tool to reconstruct deep-sea paleo-oxygen levels: The respiratory physiology of the platycopid ostracod Cytherella cf. abyssorum. Marine Biol., v. 147, no. 6, p. 1377-1386.

Donze, P. et al., 1982: Les ostracodes du Campanien Terminal a l'eocene inferieur de la coupe de Kef, Tunisie Nord-Occidental. Bull Céntre Rech Elf-Aquitaine, no. 6, p. 273-355.

Elewa, A.M.T., 2002a. Microevolution applied to ostracod biostratigraphy: the middle Cretaceous to middle Eocene ostracods of Egypt (with special reference to the genus Paracosta Siddiqui). Neues Jahrbuch für Geologie und Palaontologie Abhandlungen, v. 226, no. 3, p. 289-318.

Elewa, A.M. 2002b. Paleobiogeography of Maastrichtian to early Eocene ostracoda of North and West Africa and the Middle East. Micropaleontology, v. 48, no. 4, p. 391-398. 
Elewa, A.M.T., 2004. Quantitative analysis and palaeoecology of Eocene Ostracoda and benthonic foraminifera from Gebel Mokattam, Cairo, Egypt, Palaeogeogr., Palaeoclimat., Plalaeoecol., v. 211, nos. 3-4, p. 309323.

Elewa, A.M.T., 2007. Predation due to changes in environment: Ostracod provinciality at the Paleocene-Eocene thermal maximum in North and West Africa and the Middle East. In: Elewa, A.M.T. (Ed.): Predation in Organisms - A Distinct Phenomenon. Springer-Verlag Publishers, Heidelberg, Germany, p. 7-26.

Elewa, A.M.T., 2008a. Mass Extinction. Springer-Verlag Publishers, Heidelberg, Germany, 252 p.

Elewa, A.M.T., 2008b. Mass Extinction - A General View. In: Elewa, A.M.T. (Ed.): Mass Extinction. Springer-Verlag Publishers, Heidelberg, Germany, p. 1-6.

Elewa, A.M.T., 2008c. K-Pg Mass Extinction. In: Elewa, A.M.T. (Ed.): Mass Extinction. Springer-Verlag Publishers, Heidelberg, Germany, p. 129-132.

Elewa, A.M.T., 2014: Causes of mass extinctions - with special reference to vanishing of dinosaurs. Greener Journal of Physical Sciences, v. 4, no. 2, p. 13-21.

Elewa, A.M.T., and Dakrory, A.M., 2008a. Causes of mass extinction at the K-Pg boundary: A case study from the North African Plate. In: Elewa, A.M.T. (Ed.): Mass Extinction. Springer-Verlag Publishers, Heidelberg, Germany, p. 133-148.

Elewa, A.M.T., and Dakrory, A.M., 2008b. Patterns and causes of mass extinction at the K-Pg boundary: Planktonic foraminifera from the North African Plate. In: Elewa, A.M.T. (Ed.): Mass Extinction. Springer-Verlag Publishers, Heidelberg, Germany, p. 149-158.

Elewa, A.M.T., and Joseph, R., 2009. The History, Origins, and Causes of Mass Extinctions. Journal of Cosmology, v. 2, p. 201-220.

Elewa, A.M.T., and Morsi, A.M., 2004. Palaeobiotope analysis and palaeoenvironmental reconstruction of the Paleocene-early Eocene ostracodes from east-central Sinai, Egypt. In: Beaudoin, A.B., and Head, M.J. (Eds.): The Palynology and Micropalaeontology of Boundaries. The Geological Society, London, p. 293308.

Elewa, A.M.T., Bassiouni, M.A., and Luger, P., 1999. Multivariate data analysis as a tool for reconstructing paleoenvironments: The Maastrichtian to early Eocene Ostracoda of southern Egypt. Bulletin of the Faculty of Science, Minia University, v. 12, no. 2, p. 1-20.

Elewa, A.M.T., and Mohamed, O., 2014. Migration Routes of the Aptian to Turonian Ostracod Assemblages from North Africa and the Middle East. Paleontology Journal, v. 2014, 7 p.

El Sogher, A.M.S., 1991. Late Cretaceous and Paleocene ostracods from the Waha and Heira formations of the Sirte Basin, Libya. Unpublished M.Sc. Thesis, University of Glasgow, 210 p.

Gebhardt, H., 1999. Cenomanian to Coniacian biogeography and migration of North and West African ostracods. Cretaceous Research, 20, 215-229.

Grekoff, N., 1969. Sur la valeur stratigraphique et les relations paléogéographique de quelques ostracodes du Crétacé, du Paléocène et de l'éocène inférieur d'Algérie orientale. Proc. 3rd African Micropaléont. Coll., Cairo, p. 227-248.

Halloy, O.D', 1822. Obsemations surun essai de carte geologique de France, des Pays-Bas, et des contrkes voisines. Annales des mines et des carburants (Paris), v. 7, p. 353-76.

Hammer, Ö., Harper, D.A.T., and Ryan, P.D., 2001, PAST: Paleontological Statistics software package for education and data analysis. Palaeontologia Electronica, 4, no. 1, 9 p.

Harries, P.J., and Knorr, P.O., 2009. What does the 'Lilliput Effect' mean? Palaeogeogr., Palaeoclimatol., Palaeoecol., v. 284, no. 1-2, p. 4-10.

Herbert, T.D., 1992. Paleomagnetic calibration of Milankovitch cyclicity in Lower Cretaceous sediments. Earth and Planetary Science Letters, v. 112, no. 1, p. 15-28.

Laskar, J., Fienga, A., Gastineau, M., and Manche, H.L., 2010. A new orbital solution for the long-term motion of the Earth. Astron. Astrophys., v. 532, no. A89, p. 1-15.

Laskar, J., Robutel, P., Joutel, F., Gastineau, M., Correia, A., and Levrard, B., 2004.

A long term numerical solution for the insolation quantities of the Earth. Astron. Astrophys., v. 428, p. 261-285.

Luger, P., 2003. Palaeobiogeography of late Early Cretaceous to early Paleocene marine Ostracoda in Arabia and north to Equatorial Africa. Palaeogeogr., Palaeoclimat., Palaeoecol., Elsevier, v. 196, no. 2003, p. 319-342.

Marusek, J.A., 2005. The cosmic clock, the cycle of terrestrial mass extinctions. Lunar and Planetary Science, v. XXXVI.

Masure, A., and Vrielynck, B., 2009. Late Albian dinoflagellate cyst paleobiogeography as indicator of asymmetric sea surface temperature gradient on both hemispheres with southern high latitudes warmer than northern ones. Marine Micropaleontology, v. 70, nos. 3-4, p. 120-133. 
McAnena, A., Flögel, S., Hofmann, P., Herrle, J.O., Griesand, A., Pross, J., Talbot, H.M., Rethemeyer, J., Wallmann, K., and Wagner, T., 2013. Atlantic cooling associated with a marine biotic crisis during the mid-Cretaceous period. Nature Geoscience (Letters), v. 6, p. 558-561.

Milankovitch, M., 1920. Theorie mathematique des phenomenes thermiques produits per la radiation solaire, Gauthier-Villrs, Paris.

Milankovitch, M., 1941. Kanon der Erdbestrahlung und seine Anwendung auf das Eiszeitenproblem (Spec. Acad. R. Serbe, Belgrade).

Mitchell, R.N., Bice, D.M., Montanari, A., Cleaveland, N.C., Christianson, K.T., Coccioni, R., and Hinnov, L.A., 2008: Oceanic anoxic cycles? Orbital prelude to the Bonarelli Level (OAE 2), Earth and Planetary Science Letters, v. 267, nos. 1-2, p. 1-16.

Morsi, A.M., 2006. Aptian ostracodes from Gebel Raghawi (Maghara area) in northern Sinai, Egypt: taxonomic, biostratigraphic and paleobiogeographic contributions. Revue de Paléobiologie, Genève, v. 25, no. 2, p. $537-565$

Peypouquet, J.P., Grousset, F., and Mourguiart, P., 1986. Palaeoceanography of the Mesogean Sea based on ostracods of the Northern Tunisian Continental Shelf between the late Cretaceous and early Palaeogene. Geologische Rundschau, v. 75, p. 159-174.

Raup D.M., and Sepkoski J.J. Jr., 1984. Periodicity of extinctions in the geologic past. Proceedings of the National Academy of Science, USA, v. 81, p. 801e805.

Reyment, R.A., 1960, Studies on Nigerian Upper Cretaceous and Lower Tertiary Ostracoda: Part 1. Stockh. Contr. Geol., Stockholm, v. 7, 238 p.

Reyment, R.A., 1963. Studies on Nigerian Upper Cretaceous and Lower Tertiary Ostracoda. Part 2, Danian, Paleocene and Eocene Ostracoda. Stockh.Contr. Geol., Stockholm, v. 10, 286 p.

Reyment, R.A., 1966. Studies on Nigerian Upper Cretaceous and Lower Tertiary Ostracoda. Part 3, Stratigraphical, paleoecological and Biometrical conclusions. Stockh. Contr. Geol., Stockholm, v. 14,151p.

Reyment R.A., 1969. Ammonite biostratigraphy, continental drift and oscillatory transgressions. Nature, v. 224 , p. $137-140$.

Reyment R.A., 1971. Experimental studies of Cretaceous transgressions for Africa. Geol. Soc. Am. Bull., v. 82, p. 1063-1072.

Rosenfeld, A., and Raab, M., 1984. Lower Cretaceous ostracods from Israel and Sinai. Israel J. Earth Sci., v. 33, p. $85-134$.

Roth P.H., 1989. Ocean circulation and calcareous nannoplankton evolution during the Jurassic and Cretaceous. Palaeogeogr., Palaeoclimat., Palaeoecol., Elsevier, 74, 111-126.

Sepkoski, J.J. Jr., 1996. Patterns of Phanerozoic extinction: a perspective from global

data bases. In: Walliser, O.H. (Ed.): Global Events and Event Stratigraphy.

Springer-Verlag, Berlin, p. 35e52.

Shen, B., 2008. Global Anoxia and mass extinction at the Cenomanian-Turonian boundary triggered by subduction zone volcanism. Joint Annual Meeting, Celebrating the International Year of Planet Earth, October 5-9, Houston, Texas.

Twitchett, R.J., 2006. The palaeoclimatology, palaeoecology and palaeoenvironmental

analysis of mass extinction events. Palaeogeogr., Palaeoclimatol., Palaeoecol. v. 232, no. 2006, p. 190-213.

Tyszka, J., 2009. Foraminiferal response to seasonality modulated by orbital cycles in the Cretaceous midlatitudes: The Albian record from the Lower Saxony Basin. Palaeogeogr., Palaeoclimatol., Palaeoecol. v. 276, no. 2009, p. 148-159.

Urbanek, A., 1993. Biotic crises in the history of Upper Silurian graptoloids: a paleobiological model. Historical Biology, v. 7, no. 1993, p. 29-50.

Wade, P.S., and Twitchett, R.J., 2009: Extinction, dwarfing and the Lilliput effect. Palaeogeogr., Palaeoclimatol., Palaeoecol., v. 284, no. 2009, p. 1-3.

Whatley, R., 1991. The platycopid signal: a means of detecting kenoxic events using Ostracoda. Journal of Micropalaeontology, v. 10, no. 2, p. 181-185.

Citation: A. M. T. Elewa, "Cretaceous Ostracods of North Africa and the Middle East: Paleogeography and Paleoecology ", International Journal of Research in Environmental Science, vol. 4, no. 2, p. 11-21, 2018. http://dx.doi.org/ 10.20431/2454-9444.0402002

Copyright: (C) 2018 A. M. T. Elewa. This is an open-access article distributed under the terms of the Creative Commons Attribution License, which permits unrestricted use, distribution, and reproduction in any medium, provided the original author and source are credited. 